\title{
BÓDI-SCHUBERT Anikó
}

\section{A VEVŐ-BESZÁLLÍTÓ KAPCSOLAT ELMÉLETI MEGKÖZELÍTÉSEI ÉS EMPIRIKUS SZEMLÉLTETÉSÜK}

A cikk célja, hogy bemutassa a vállalatok, ezen belül kiemelten vevố és beszállító közötti kapcsolatok jelentéstartalmának elméleti megközelítéseit. Ehhez kapcsolódóan az írás két fố egységre tagolódik: az elsố szakaszban a vevố-beszállító kapcsolat fogalmának kifejtésekor ismerteti azok kialakulásának, a tranzakciók szintjéról kiinduló fejlódésének lehetséges állomásait, továbbá egy elméleti vizsgálati keretet mutat be, amelynek segítségével a cikk fókuszában álló kapcsolatok elemezhetốk, belsố struktúrájuk feltárható. A vállalatok közötti kapcsolatok vizsgálatával, tartalmának elemzésével több elméleti irányzat foglalkozik. Jelen írás a vevốk és beszállítók közötti kapcsolat definiálása és a felek közötti viszonyrendszert elemző elméleti megközelítések ismertetése során alapvetôen az Industrial Marketing and Purchasing Group nemzetközi kutatócsoport által alkotott és elfogadott elméletekre támaszkodik, fóként azok nemzetközi publikációkban ismertetett eredményeit szintetizálja. Az írás második tartalmi egységében az ismertetett elméletek gyakorlatban való megjelenését, értelmezhetôségét esettanulmány szemlélteti.

Kulcsszavak: vevố, beszállító, kapcsolat, interakció, epizód, tranzakció

Az üzleti, ezen belül a vevô-beszállító közötti kapcsolatok vizsgálata nemcsak az egyes diadikus kapcsolatok struktúrájának megértése szempontjából lényeges; a kapcsolat a hálózati gazdaságnak is kiemelt eleme, hiszen az egyes üzleti hálózatok felépítésének megértése, struktúrájának megragadása a „benne található” kapcsolatok segítségével lehetséges. Ahhoz, hogy részletesen tudjunk elemezni egy hálózatot, az egyes kapcsolatokra vonatkozóan pontos és alapos ismeretekkel, információkkal kell rendelkeznünk (Gelei, 2009).

A cikk célja, hogy elsősorban irodalomkutatás eredményei alapján feltáró-rendszerezô elemzést adjon a vevő-beszállító kapcsolat jelentéséról, kialakulásának fejlődési fázisairól, illetve a létrejött kapcsolatok struktúrájának elemzési keretéról. A kapcsolat vizsgálata során az írás elsősorban az Industrial Marketing and Purchasing Group (továbbiakban IMP) megközelítésére támaszkodik majd, ám egyes helyeken más kapcsolódó elméleti iskolák, mint például a kapcsolati szerződéselmélet nézeteit is bemutatja. Az írás kitüntetett fogalmai közé tartozik a vállalatok közötti tranzakció, interakció, kapcsolat és együttmúködés jelentéstartalmának elemzése, illetve a már létrejött kapcsolat belsô felépítését, tartalmát vizsgáló elméleti modellek bemutatása. A kapcsolat fejlódésére, illetve struktúrájának lehetséges leírására vonatkozó elméleti modelleket a cikk utolsó szakaszában esettanulmány szemlélteti.

\section{A vállalatok közötti kapcsolat kialakulásának kitüntetett lépései az IMP megközelítésében}

Jelen fejezet arra vállalkozik, hogy elsôsorban az IMP kutatóinak megközelítését alkalmazva megragadja a vállalatok közötti, ezen belül kiemelten a vevő-beszállító kapcsolat pontos jelentését, s részletesen tárgyalja a kapcsolat kialakulásának szakaszait, ehhez kapcsolódóan leírja a kapcsolat egyes fejlődési fázisainak fó folyamatait, s bemutassa azok lényeges tulajdonságait.

A vállalatok közötti kapcsolat vizsgálatával, jellemzóinek elemzésével számos kutató foglalkozik, ám mégis kevés publikációban találunk konkrét és precíz definíciót a kapcsolat szó jelentésének megadására, 
értelmezésére. A legtöbb szerző evidensnek és egyértelmúnek tekinti a kapcsolat értelmezését, ezért csak implicit leírásokkal él, s általában két vállalat értékteremtô céllal létrejövő együttmúkoödését érti alatta (Ellram - Hendrick, 1996; Dyer, 1997; Bensaou, 1999; Cox 2001; 2004).

Az elemzés fókuszában álló vevő-beszállító kapcsolat tartalmának pontos megértéséhez ismerni szükséges az üzleti kapcsolat létrejöttének fontosabb mérföldköveit. A kapcsolatok kialakulásának kiindulópontját a vállalatok közötti csere, vagy más néven tranzakció ${ }^{1}$ jelenti. A tranzakció fogalmát Ford és szerzôtársai (2007: 7. old.) szereplő́k vagy aktorok közötti egyszeri, lehatárolt, konkrét tartalommal bíró termék, szolgáltatás vagy pénztranszferként határozzák meg. A tranzakció egyfajta felek közötti mechanizmusként értelmezhetó, amely az aktorok közötti ügylet bonyolításának idejére összeköti a szereplőket, ám önálló tartalma korlátozott. A transzfer kölcsönös, a szereplók szükségletein alapszik, de lebonyolítása nem igényli az aktorok jelentôs, elmélyült egymásra hatását, az egymáshoz való alkalmazkodást. A szereplók közötti csere sematikus folyamatát az 1. ábra szemlélteti.

\section{A vállalatok közötti csere vagy tranzakció}

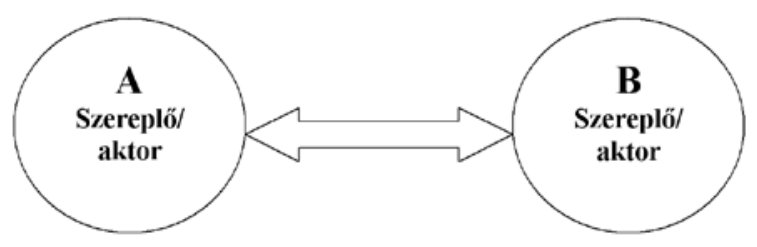

Forrás: Ford et al. $(2008,8$. o.)

Håkansson (1982) a vállalatok közötti egyedi, különböző tárgyú, egyszerú cserék, tranzakciók sorozatait epizódoknak ${ }^{2}$ nevezi. Az epizódok hangsúlyos eleme - a tranzakciókhoz hasonlóan - a felek közötti termékés szolgáltatáscsere, amelynek jellemzóit alapvetóen meghatározza, hogy jól körülírhatók-e a vevői igények, illetve a termékjellemzók mennyire komplexen definiálhatók. A termékeket kíséró információcsere az epizódok újabb összetevője, amely állhat formális és informális, jól és rosszul strukturált elemekból, illetve tartalmazhat jellemzően személyek közötti, továbbá szervezetközi elemeket. A termék- és szolgáltatáscserét pénzügyi teljesitési folyamat is követi, amelynek formája és feltételei sok esetben bizonytalansági tényezóit jelentik az epizódoknak. Az epizódok a felsorolt tranzakciók esetében már megjelent elemeken kívül szociokulturális tényezóket is tartalmaznak, amelyek olyan jellemzóket ötvöznek magukban, mint a felek közötti kulturális attitúdök, a kölcsönös bizalom, illetve annak építésére való törekvés. A szociokulturális elemek általában a legnehezebben definiálható, legpuhább elemei a kapcsolatoknak. Az egyes tranzakciókban és epizódokban, illetve azokhoz kapcsolódóan egyedi és kölcsönös akciók (Holmund, 2004) zajlanak a vállalatok között, amelyek lehetnek operatív részletekról való egyeztetések, a rendelések feladásai és fogadásai, kiszállítások, vagy akár telefonhívások is. Az akciók tehát a felek önálló tevékenységeit foglalják magukban, amelyek egymáshoz való sorozatos kapcsolódása már magát az epizódot testesíti meg.

A vállalatok közötti együttmúködés folyamataihoz köthetố az interakció jelensége, amely az aktorok közötti epizódok sorozata révén alakul ki, és olyan viszonyrendszert hoz létre, ahol két szereplő között egy, a felek által alkotott, ám külön-külön nem kontrollálható és/ vagy irányítható struktúra jön létre (Ford et al., 2008). $\mathrm{Az}$ aktorok közötti interakciót a 2. ábra illusztrálja, amelyen jól látható, hogy az interakció az együttmúködés során kialakuló, a részt vevő feleken túlmutató, a felek közös akaratával irányítható komplex, független folyamathalmazt jelöl. Blois (1972) szerint a vállalatok közötti interakció folyamatai olyan jelentőségteljessé válhatnak, hogy kvázi-szervezeti tulajdonságokat vesznek fel, s ezzel az interakció tovább intézményesülve vállalatok közötti kapcsolattá válik. Az interakció során a vállalatok közötti együttmúköódésben végbemenô akciókra adott válaszok és viszontválaszok legalább olyan fontosak, mint maga az eredeti akció (Mandják, 2005). Az interakció tehát a vállalatok közötti együttmúködésben a folyamatok szintjén értelmezhetô, tudatosan menedzselt folyamatrendszer, amely hozzájárul az együttmúköőô felek közötti kapcsolódási pontok intézményesüléséhez, a szereplők közötti szilárd kapcsolatok kialakulásához.

\section{A vállalatok közötti interakció}

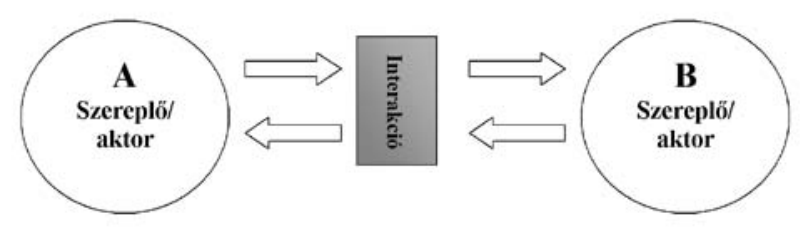

Forrás: Ford et al. (2008, 9. o.)

Az IMP kutatóinak felfogásában (Håkansson, 1982; Ford et al., 1986) az epizódok ismétlésének sorozataként alakulnak ki az interakció folyamatai, amelyek révén az epizódok mindkét fél múködésében beépülnek a szervezeti rutinok közé. A rutinok ahhoz segítik hozzá a szervezeteket, hogy az epizódok intézményesüljenek, ezáltal a kapcsolatok formalizálódnak, a tranzakciók költségei csökkennek, a felek közötti kötelékek létre- 
jönnek, s tovább erôsödnek, a felek kölcsönösen „kapcsolódottá válnak". Ezt az intézményesülést támogatja a fent említett interakció kialakulása, illetve az abban zajló folyamatok szervezetté válása. A másik féllel szemben támasztott elvárások, a kapcsolatot jellemző rutinok, együttmúködési gyakorlatok megszilárdulnak, s a jövőorientált szemléletmód és viselkedés jellemzi az együttmúködést. Az interakció és a rutinok segítségével hosszú távú kapcsolatok alakulnak ki. A kapcsolat az interakcióhoz képest három fó paraméterben jelent szorosabb összekapcsolódottságot (Holmund, 2004 alapján):

1) idódimenzióval rendelkezik, azaz van „múltja”, amelynek tapasztalata beépül a rutinokba,

2) egyértelmúen intézményesült, azaz folyamatait szilárd, formalizált együttmúködés jellemzi, amelyet gyakran keretszerződés alapoz meg,

3) kölcsönös adaptáció alakul ki a folyamatok szintjén a felek közötti együttmúködés során,

4) jövóorientált, a múltból ered, de alapvetôen „elôre mutat”.

Az IMP vállalatok közötti kapcsolatfelfogást jól összegzi neves kutatóinak - Anderson és Narus (1991: 98. old.) - vevő-beszállító kapcsolatról alkotott definíciója: „A kapcsolat a vevő és beszállító vállalatok között létrejövő struktúra, amelyben a felek szociális, gazdasági és technológiai kötelékeket alakítanak ki azzal a céllal, hogy csökkenő költségeket realizáljanak és/vagy növekvő értéket teremtsenek, miközben kölcsönös elónyökre tesznek szert."

A vevók és beszállítók közötti kapcsolat lényegi elemeinek kifejtésére Håkansson és szerzôtársai (Håkansson - Johansson, 1992; Håkansson - Snehota, 1995) az úgynevezett $A-R-A$ modellt alkalmazzák. A szerzók szerint a vevớk és beszállítók közötti kapcsolatok „összekapcsolódottságát” három fő összekötó kapcsolódási szál fejezi ki: a kapcsolatot alkotó szereplók ${ }^{3}$, a tevékenységek és a szereplók által birtokolt eróforrások, innen ered a betúszavakkal rövidített modell elnevezése. A szereplók kapcsolódási szál a kapcsolatot alkotó felek közötti interperszonális viszonyokat jeleníti meg, s azokat az attitúdöket, érzelmeket, normákat tömöríti, amelyek alapján eldől a felek közötti bizalom, elkötelezettség, elismerés és befolyás mértéke. A tevékenységek kapcsolódási szál a felek közötti kapcsolat során végbemenő folyamatok integráltságának, illetve közös koordinációjának a létét, megvalósulását fejezi ki. A kapcsolat résztvevới között zajló anyagi folyamatok s az ezeket kísérő információs folyamatok (mint például a keresletmenedzsment, disztribúció, vevókiszolgálás, dokumentumok kezelése) különböző mértékben lehet- nek integráltak, s ezáltal a tevékenységek által generált „összekapcsolódottság” mértéke is különböző. A felek által birtokolt eróforrások egymáshoz való kölcsönös alkalmazkodása a felek közötti kapcsolatot meghatározó harmadik lényeges kapcsolódási szál. A kapcsolatot alkotó felek egyes eróforrásai folyamatosan konfrontálódnak és/vagy alkalmazkodnak egymáshoz, amelynek eredményeként az összekapcsolódottságot elmélyító közös erőforrások jöhetnek létre a kapcsolatokban. Az említett három kapcsolódási szál sem független egymástól, hanem szoros kölcsönhatásban állnak: a tevékenységek támogathatják, vagy éppen akadályozhatják az erőforrások egymáshoz való alkalmazkodását, az erőforrások limitálhatják vagy ösztönözhetik a tevékenységek közötti integrációt, és a szereplók felfedezhetik vagy elodázhatják az erôforrások alkalmazkodásának és a tevékenységek közötti integráció elmélyítésének lehetőségeit. A szereplő́k, tevékenységek és erőforrások közötti kapcsolódási szálak nemcsak annak a konkrét kapcsolatnak az elemeit kötik össze egymással, amelyben léteznek, hanem ezek által épülnek ki az adott kapcsolatot további kapcsolatokkal összekötő hidak is, így a nevezett három elemet az adott kapcsolatot körülvevő hálózat építőelemeinek is tekinthetjük. Ebból következően Mandják (2005) az üzleti kapcsolatot e három felsorolt kapcsolódási szál sajátos fonatának tekinti.

\section{A vállalatok közötti kapcsolat és együttmúködés egyéb megközelítései}

Az IMP kutatóinak kapcsolatmeghatározásai mellett természetesen több elméleti megközelítés is létezik az üzleti kapcsolat tartalmának, fogalmának meghatározására. Jelen fejezetben elsôsorban a kapcsolati szerzódéselmélet, illetve a logisztikai, ellátási képességek oldaláról kiinduló megközelítések legfontosabb megállapításainak összegzését teszem meg. Annak érdekében, hogy világos és pontos fogalmi képet kapjunk a vállalatok között kialakuló folyamatok, struktúrák jelentéstartalmáról, szükségesnek tartom meghatározni a vállalatok közötti együttmúködés és a partnerkapcsolat jelentését, s ezáltal megadni az üzleti kapcsolattól való elkülönítésüknek szempontjait. Gyakran előfordul ugyanis, hogy ezeket a fogalmakat szinonimaként használják az üzleti kapcsolattal, ám - bár hasonló tartalom kifejezésére irányulnak - nem teljesen azonosan értelmezhető a három kifejezés.

A vállalatok közötti együttmúködés, kooperáció fogalmának meghatározására kevés az egzakt definíció az irodalomban. Számos forrás gyakorlatilag két vállalat között létrejövő, különbözó mértékben koordinált közös tevékenységet ért alatta (Andaleeb, 1995; Tietz 
1993). Agárdi (2005) az együttmúködést/kooperációt a vállalatok közötti közös cselekmények gyújtôfogalmának tekinti, s a következő jellemzóket tartja rá érvényesnek:

- vállalatközi megállapodáson alapul, amely azonban nem feltétlenül szerződésben ölt testet, jellemzően inkább rendszeresen ismételt tranzakciók (epizódokban) eredményeként jelentkezik,

- tulajdonjogilag független partnerek között megy végbe,

- közös erőforrás-felhasználás és a részt vevő felek érdekeinek kölcsönös figyelembevétele jellemzi.

A vállalatok közötti együttmúködés meghatározásában a rövid és hosszú távú orientáció, illetve az aktorok közötti tevékenység összehangoltsága és értékteremtő irányultsága közötti különbözőség jelenik meg Macneil (1980) kapcsolati szerződéselméletének ${ }^{4}$, illetve ennek alapján Dwyer és szerzốtársainak (1987) megközelítésében is, akik a vállalatok közötti együttmúköós két végpontját határozzák meg: a diszkrét, illetve kapcsolati tranzakciókat. A diszkrét tranzakciók egyszeriek, kismértékú kommunikáció és szúk, jól fókuszált paraméterekkel pontosan meghatározott tartalom jellemzi óket. A kapcsolati tranzakciók korábbi események és jövóbeli tranzakciók kontinuumába beágyazottan jelentkeznek, explicit és implicit feltételezések, bizalom és közös tervezés jelenik meg bennük (Agárdi, 2005). A diszkrét és kapcsolati tranzakciók összehasonlítását az 1. táblázat mutatja be.

1. táblázat

Diszkrét és kapcsolati tranzakciók

\begin{tabular}{|c|c|c|}
\hline $\begin{array}{l}\text { Az összehasonlítás } \\
\text { szempontjai }\end{array}$ & Diszkrét tranzakció & Kapcsolati tranzakció \\
\hline $\begin{array}{l}\text { Tranzakció idóbeli } \\
\text { jellemzői }\end{array}$ & $\begin{array}{l}\text { Rövid távú tranzakció, amely véget ér a } \\
\text { szerzôdésben vállalt feladat befejezésével. }\end{array}$ & $\begin{array}{l}\text { A tranzakció egy folyamat része, korábbi megállapodások- } \\
\text { hoz kötő́dik, jövőorientáció jellemzi. }\end{array}$ \\
\hline Partnerek száma & Két partnerre korlátozódik. & $\begin{array}{l}\text { A tranzakció folyamatában akár kettónél több partner is részt } \\
\text { vehet (hálózat kialakulásának irányába mutat). }\end{array}$ \\
\hline $\begin{array}{l}\text { Tranzakció tartalma és } \\
\text { specifikussága }\end{array}$ & $\begin{array}{l}\text { A tranzakció tartalmát egyszerú igény } \\
\text { határozza meg, a vállalt kötelezettségek } \\
\text { standardizáltak, szokásokon és } \\
\text { meggyőző́déseken alapulnak. }\end{array}$ & $\begin{array}{l}\text { A kötelezettségek testreszabottak és részletesek, tartalmukat } \\
\text { és forrásukat a kapcsolat során tett ígéretek adják, amelyek- } \\
\text { hez a szokások és a jog is hozzáadódnak. }\end{array}$ \\
\hline $\begin{array}{l}\text { A kapcsolatról megfogal- } \\
\text { mazott várakozások }\end{array}$ & $\begin{array}{l}\text { Célok közötti érdekkonfliktusok várhatók, } \\
\text { nem jellemző a felek közötti egység. }\end{array}$ & $\begin{array}{l}\text { A jövőbeni problémákat és várható érdekkonfliktusokat a } \\
\text { bizalomra és akarategységre támaszkodva próbálják kezelni. }\end{array}$ \\
\hline $\begin{array}{l}\text { Személyes kapcsolatok } \\
\text { jelentősége }\end{array}$ & $\begin{array}{l}\text { Rutinszerú, sablonos kommunikáció és } \\
\text { minimális személyes kontaktus jellemzi. }\end{array}$ & $\begin{array}{l}\text { Széles körú formális és informális kommunikáció, személyes } \\
\text { kapcsolatok alakulnak ki, nemüzleti jellegú elégedettség } \\
\text { keletkezik. }\end{array}$ \\
\hline Szerződéses szolidaritás & $\begin{array}{l}\text { Alapvetóen az önérdek a meghatározó, } \\
\text { elfogadja és követi a társadalmi normákat. }\end{array}$ & $\begin{array}{l}\text { Az önszabályozás jelentôsége növekszik, belsô kapcsolati } \\
\text { alkalmazkodás. }\end{array}$ \\
\hline $\begin{array}{l}\text { Jogok és kötelezettségek } \\
\text { átruházhatósága }\end{array}$ & $\begin{array}{l}\text { Teljes mértékú átruházhatóság, irreleváns, } \\
\text { hogy ki teljesíti a szerződést. }\end{array}$ & $\begin{array}{l}\text { Korlátozott átruházhatóság, a tranzakció nagyban függ a } \\
\text { felek identitásától. }\end{array}$ \\
\hline $\begin{array}{l}\text { Kooperáció (a közös } \\
\text { tervezésre és teljesítésre } \\
\text { irányuló erófeszítések) }\end{array}$ & Nem jellemzố a kooperáció. & $\begin{array}{l}\text { A partnerek jelentős erófeszítéseket tesznek a közös } \\
\text { tervezésre és a közösen támasztott teljesítmények elérésére. }\end{array}$ \\
\hline Tervezési folyamat & $\begin{array}{l}\text { Koncentrálás az egyedi tranzakcióra, nincs } \\
\text { jövőorientált tervezés. }\end{array}$ & $\begin{array}{l}\text { A jövóbeni tranzakciók részletes tervezése, változó célok } \\
\text { megvalósítása, hangsúly az együttmúködés folyamatán. }\end{array}$ \\
\hline $\begin{array}{l}\text { Teljesítménymérés és } \\
\text { specifikáció }\end{array}$ & $\begin{array}{l}\text { A teljesítmény egyértelmúen mérhető, } \\
\text { kevés figyelmet fordítanak a specifikációra. }\end{array}$ & $\begin{array}{l}\text { A teljesítmény minden aspektusának mérése, specifikálása } \\
\text { és számszerúsítése, amely a várható jövoóbeli előnyöket is } \\
\text { magában foglalja. }\end{array}$ \\
\hline $\begin{array}{l}\text { Hatalom (mások befolyá- } \\
\text { solásának képessége) }\end{array}$ & $\begin{array}{l}\text { Csak szerző́désszegés esetén releváns a } \\
\text { hatalmi befolyásolás. }\end{array}$ & $\begin{array}{l}\text { A megnövekedett függóség a hatalom érvényesítéséhez } \\
\text { vezet. }\end{array}$ \\
\hline $\begin{array}{l}\text { Előnyök és hátrányok } \\
\text { szereplők közötti meg- } \\
\text { osztása }\end{array}$ & $\begin{array}{l}\text { Az előnyök és hátrányok egyértelmúen } \\
\text { szétválaszthatók, s a partnerekhez } \\
\text { rendelhetôk. }\end{array}$ & $\begin{array}{l}\text { Az előnyök és hátrányok nem rendelhetốk partnerhez, } \\
\text { a szerzôdés idôtartama alatt törekszenek azok elosztására. }\end{array}$ \\
\hline
\end{tabular}

Forrás: Dwyer et al. (1987: 13. o.) és Macneil (1980) alapján 
A vállalatok közötti együttmúködés és kapcsolat fogalmának részletes kibontása mellett fontos definiálni a partnerkapcsolat kifejezés jelentéstartalmát is. Annak ellenére, hogy a magyar nyelv - az angoltól eltéróen, amely a kapcsolatot, illetve partnerkapcsolatot két teljesen eltéró kifejezéssel jelöli - közel azonosan nevezi ôket, a két fogalom eltérő jelentéstartalmat tükröz. A vállalatok közötti partnerkapcsolat (partnership) meghatározására cikkemben Mohr és Spekman (1994: 135. o.) definícióját fogadom el, amely szerint: ,,a partnerkapcsolatok független vállalatok közötti, tudatos céllal létrehozott stratégiai kapcsolatok, amelyekben a résztvevők összeegyeztethetô célokkal rendelkeznek, kölcsönös előnyök elérésére törekszenek, s tudomásul veszik a kapcsolat által kialakult erôs kölcsönös függőséget”. A partnerkapcsolat definíciójához sorolható ${ }^{5}$ Ring és Van de Ven (1993: 5. o.) megközelítése is, akik formális jogi és informális szociálpszichológiai aspektusból vizsgálják a vállalatközi kapcsolatokat, s a következóképp határozzák meg jelentésüket: „,a kapcsolat egy vállalatnak egy másik vállalattal tett közös és ismétlődő erőfeszítése arra, hogy szerződéses alapon idioszinkretikus ${ }^{6}$ beruházásokat hozzanak létre".

A fenti definíciókból jól érzékelhetô, hogy a partnerkapcsolat kölcsönös stratégiai azonosságot, hoszszú távú elkötelezettséget s kapcsolatspecifikus beruházások létét tételezi fel az azt alkotó felek között, ezért a „szimpla” kapcsolathoz képest jóval szorosabb kölcsönös függőségi rendszert és tudatosabban menedzselt struktúrát jelöl. Így jelentése nagyon közel áll a kapcsolati szerződéselmélet által meghatározott kapcsolati tranzakció leírásához és tartalmához. Az IMP kutatói megközelítéséhez képest a partnerkapcsolat-definíciók egy komplexebb, elmélyültebb vevő-beszállító viszonyrendszerre utalnak, amely közelebb áll a vállalatok közötti együttmúködést a logisztikai, ellátási képességek szempontjából vizsgáló számos szerző (Bensaou, 1999; Cox, 2004a, b; Ellram - Hendrick, 1995) kapcsolatfelfogásához is, jóllehet ók publikációik során nem alkottak pontos, egzakt definíciókat.

\section{A bemutatott üzleti kapcsolat megközelítések szintetizálása és a kapcsolat fejlődése}

Cikkem e fejezetében ismertetem az eddig bemutatott elméletek szintetizálásának lehetőségeit, a megközelítésükben tapasztalható hasonlóságokat és különbözőségeket, illetve a fejezet második szakaszában bemutatom az üzleti kapcsolat fejlődésének egy, szintén az IMP kutatója által alkotott elméleti keretét.

\section{Az ismertetett üzleti kapcsolat megközelítések szintetizálása}

Az IMP kutatóinak és a kapcsolati szerződéselmélet elfogadóinak a vállalatok közötti kapcsolatokról alkotott felfogásában több hasonlóságot fedezhetünk fel. A cserék nyomán létrejövő epizódokat gyakorlatilag diszkrét tranzakcióknak tekinthetjük, míg a kapcsolati tranzakciók olyan kapcsolatokat jelölhetnek, amelyek A-R-A modell szerinti - összekapcsolódottsága jelentôsnek tekinthetô. A két szemlélet közötti legfontosabb lényegi különbözőség, hogy az IMP felfogása megenged különböző „összekapcsolódottsági” mértéket, azaz kevésbé szorosnak tekinthető együttmúködést is kapcsolatként értelmez, ezzel szemben Macneil (1980), illetve Dwyer (1987) felfogásában a kapcsolati tranzakciók már elmélyültebb, kiterjedt múltbeli tapasztalaton nyugvó, de jövőorientált szoros köteléket tekintenek kapcsolatnak. Az értelmezésük szerinti kapcsolaton inkább a partnerkapcsolat jelentését ,érhetjük tetten”.

Jelentéstartalmában az együttmúködés az IMP kapcsolatfelfogásában fớként az interakcióhoz állhat közel, de nézőpontom szerint folyamatainak intézményesültsége és tudatos „menedzseltsége” jóval elmaradhat az interakcióétól, akár már epizódszinten is észlelhetünk vállalatok közötti együttmúködést. A partnerkapcsolat egy szoros kapcsolati tranzakciót foglalhat magában, $\mathrm{s}$ az IMP kapcsolatfelfogásában ,elhelyezve” egy rendkívül erős összekapcsolódottságot jelölhet, a felek közötti folyamatok magas szintú intézményesülését testesítheti meg. Az elózóekben bemutatott vállalatok közötti tranzakció, epizódkapcsolat, interakció és partnerkapcsolat meghatározásainak különböző jelentéstartalmát a 3. ábrával illusztrálom (következố oldalon).

A 3. ábrát egy példával szemléltetve a következôképp értelmezhetố a tranzakciók szintjétól a partnerkapcsolat létrejöttéig történő fejlődési folyamat:

- egy gyốztes tender eredményeként egyszeri adásvétel történik a vevố és a beszállító között tranzakció szintje,

- a vevő elégedett volt a termékkel és a kiszolgálással, 1́gy a tranzakció többször megismétlődik, ehhez kapcsolódóan különböző akciók (megrendelések feladása, számlázás, munkatársak közötti egyeztetések) zajlanak a vállalatok között epizód szintje,

- az epizódok alatt a felek között pozitív személyes és formális kapcsolatok alakulnak ki, közösen törekszenek növelni a termék forgalmát, például különböző promóciókat szerveznek, törekszenek a rendelésfeladási és -teljesítési folyamat egyszerúsítésére, egymás múködésének megértésére interakció szintje, 
- a felek saját igényeikre testre szabott, hosszú távú keretszerződést kötnek, elmélyítik a kapcsolat közös és tudatos menedzselésére vonatkozó tevékenységüket (például együttes keresletmenedzsment: előrejelzések, kategóriamenedzsment, testre szabott választék kialakítása stb.) kapcsolat szintje,

- vevő és beszállító kapcsolatspecifikus beruházásokat tesznek, például EDIrendszert vezetnek be, s bizalmas információkat is megosztanak egymással (készletadatok), közös termékfejlesztést hajtanak végre partnerkapcsolat szintje.

Az elôző szakaszokban ismertetett fogalmi keretból kiindulva, a vállalatok közötti kapcsolat definíciójára vonatkozóan az alábbi elemeket emelhetjük ki mint a kapcsolat jelentésének letéteményeseit:

- két vállalat kölcsönös, önkéntes és koordinált tevékenysége,

- hosszú távú orientáció, kölcsönös adaptáció és jelentôs, felek közötti „összekapcsolódottság” jellemzi, amely túlmutathat az egyes vállalatok szervezeti keretein,

- a felek által elfogadott, közös cél érdekében jön létre,

- amelynek eredményeként kölcsönösen értéket teremtenek egymás számára.

\section{A kapcsolat kialakulása, fejlódési fázisai}

Tovább folytatva az IMP kutatóinak az üzleti kapcsolat jelentését, fejlődését tárgyaló publikációinak bemutatását, ebben az alfejezetben a vállalatok közötti kapcsolat
Diszkrét

tranzakció
3. ábra

A vállalatok közötti kapcsolatmeghatározások rendszerezése

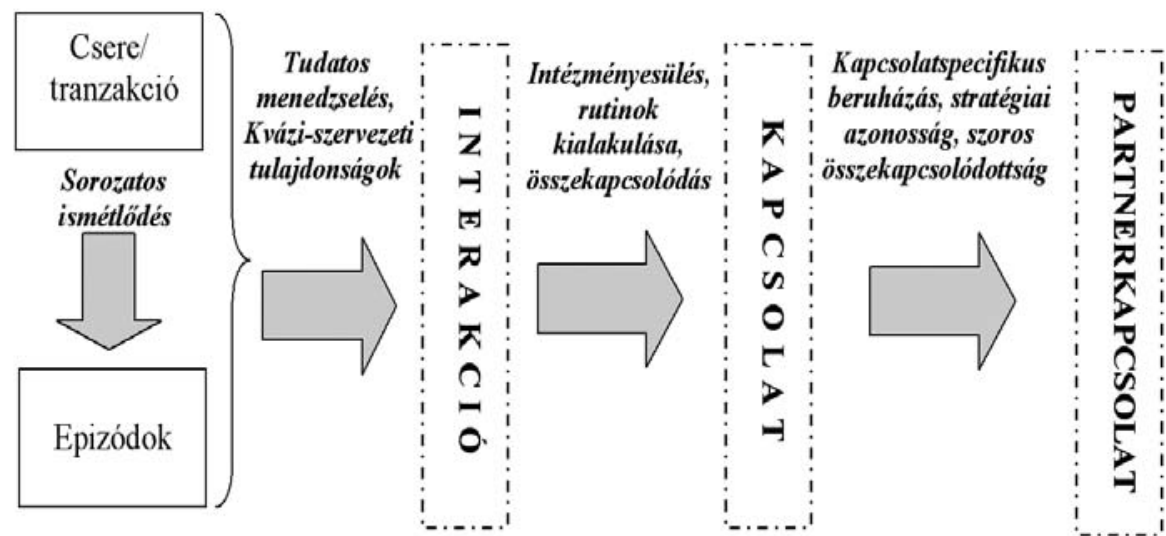
Kötelékek erősödése,
intézményesülés
Kapcsolati

tranzakció
Forrás: saját szerkesztés

kialakulásának lehetséges folyamatát ismertetem, öszszefoglalva Ford (1998) elméletét.

A vevó-beszállító kapcsolatok kialakulását legtöbb szerzó időben elhúzódó, többlépcsốs fejlódés eredményének tekinti. Ford (1998) egy négyfokozatú fejlődési skála eredményeként értelmezi a stabil vevő-beszállító partnerkapcsolat létrejöttét, s felfogása szerint e kapcsolatok születése a 4 . ábra segítségével illusztrált folyamatként írható le.

A vevő-beszállító kapcsolatok születése

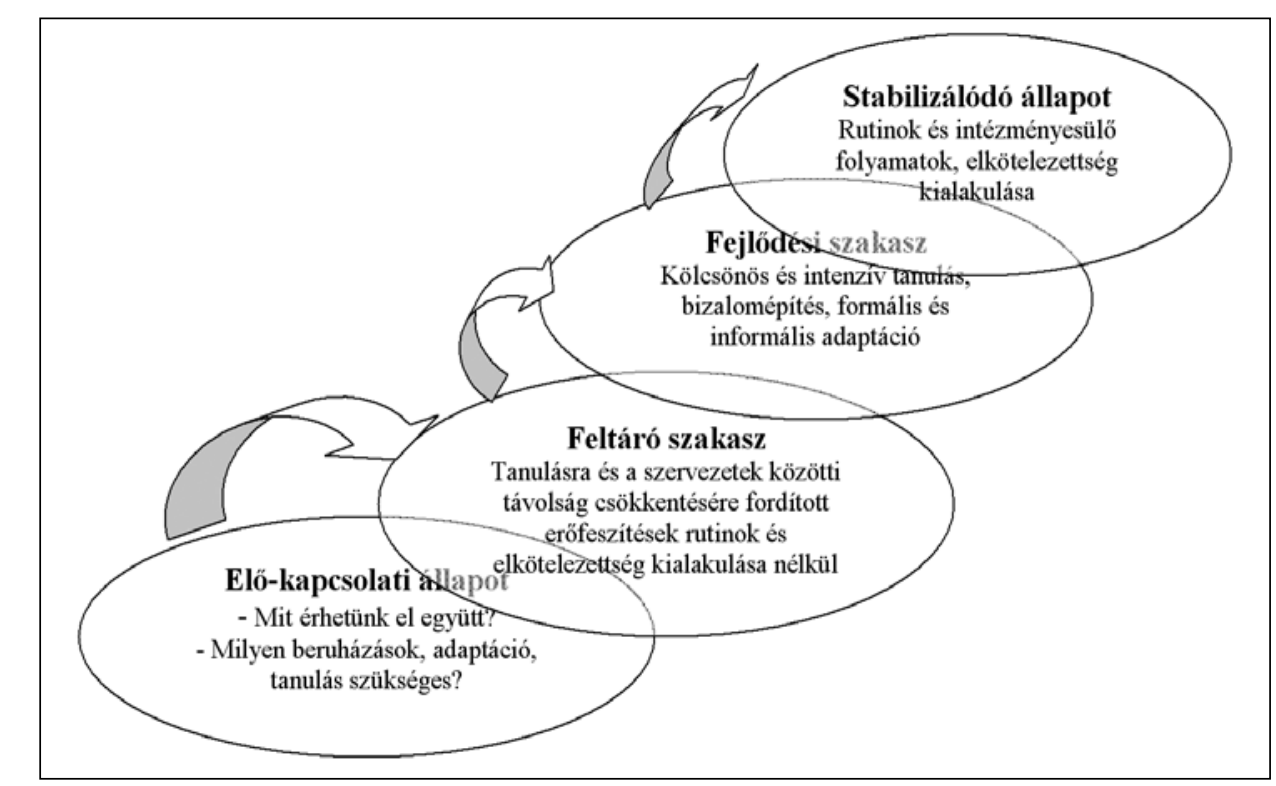

Forrás: Ford, 1998: 29. o. 
Előkapcsolati állapotban a leendô partnerek mérlegelik, hogy érdemes-e kapcsolatba lépniük a másik féllel, milyen előnyöket és költségeket várhatnak a kezdeményezéstól. Ebben a szakaszban különböző tranzakciók, epizódok szintjén zajlik a felek közötti együttmúködés, ám már fokozatosan megjelenik a közös jövôkép felvázolása is. Miután a felek a kapcsolat kialakítása mellett döntöttek - azaz létrejön az interakció, a felek között erôsödő kötelékek jönnek létre -, megkezdődik a kölcsönös tanulás, az egymással való együttmúködés potenciális előnyeinek feltárása, a felek „összecsiszolódása”.

A fejlődési szakaszban a felek között zajló folyamatok mélyebb megértése és fejlesztése zajlik, kialakul az elkötelezettség és a bizalom, felerősödik az együttmúködési folyamatokban tapasztalható adaptáció, hangsúlyossá válik az interakció folyamatainak intézményesülése. Stabil állapotban a kapcsolat elmélyül, az együttmúködés folyamatai rutinokká válnak, s jelentôs mértékben intézményesülnek. Ez utóbbi két fázisban az interakció folyamatai során fokozatosan mélyülnek a felek közötti kötelékek, végül a rutinok kialakulásával az interakció megszilárdul, a felek összekapcsolódottá válnak, s létrejön a kapcsolat. Fontos azonban hangsúlyozni, hogy az üzleti kapcsolat folyamatosan fejlődik, változik, nincs végső állapota. A stabilnak mondott kapcsolat történetében is bekövetkezhetnek hullámvölgyek, amelyek egy korábbi, fejlettebb állapothoz képest visszalépést eredményezhetnek. Természetesen ennek az ellentéte is tapasztalható, amikor a kapcsolat folyamatosan mélyül, s a felek közötti kötelékek tartósan erôsödnek (Ford és szerzőtársai, 2007).

\section{A vevố-beszállító kapcsolat rendszerének elemzése}

Cikkem jelen fejezetében bemutatom az IMP Group többéves nemzetközi kutatási eredményeit ötvöző elméleti keretét, az interakció ${ }^{7}$-megközelítést (Interaction Approach, továbbiakban IA), amely a vevő-beszállító kapcsolat rendszere elemzésének az egyik legkorábbi és talán legkomplexebb megközelítését adja (Håkansson, 1982).

Az IMP Group a vállalatok közötti kapcsolatok elemzésekor a kapcsolatok hosszú távú orientációjára, illetve a kapcsolatokat jellemző dinamikára helyezi a hangsúlyt. A széles körú nemzetközi kutatás eredményeként konstruált IA célja, hogy olyan átfogó fogalmi keretet teremtsen, amelynek segítségével a szervezetközi kapcsolatok, így különösen a vevő-beszállító kapcsolatok kialakulása, múködése, fejlődése, fenntartása, illetve az ezeket a folyamatokat jellemző dinamika érthetôvé és megragadhatóvá válik. Az IA legfontosabb pilléreit az üzleti kapcsolatokat létrehozó felek (személyek és szervezetek egyaránt); a közöttük kialakuló interakciós folyamatok; az atmoszféra, amely a felekkel kölcsönhatásban áll, illetve a környezet, amely a feleket és folyamatokat „körbeveszi” jelentik. Az IA legfőbb elemeit, illetve azoknak egymáshoz való viszonyát az 5. ábra segítségével szemléltetem.

Az interakció folyamatai a felek közötti csereepizódokra épülnek, amely epizódoknak a cikk elsô fejezetében ismertetett négy fő típusát azonosítja Håkansson.

\section{5. ábra}

\section{Az interakció modell}

Környezet

(piaci szerkezet, dinamizmus, ellátási láncban elfoglalt pozíció, társadalmi viszonyok)

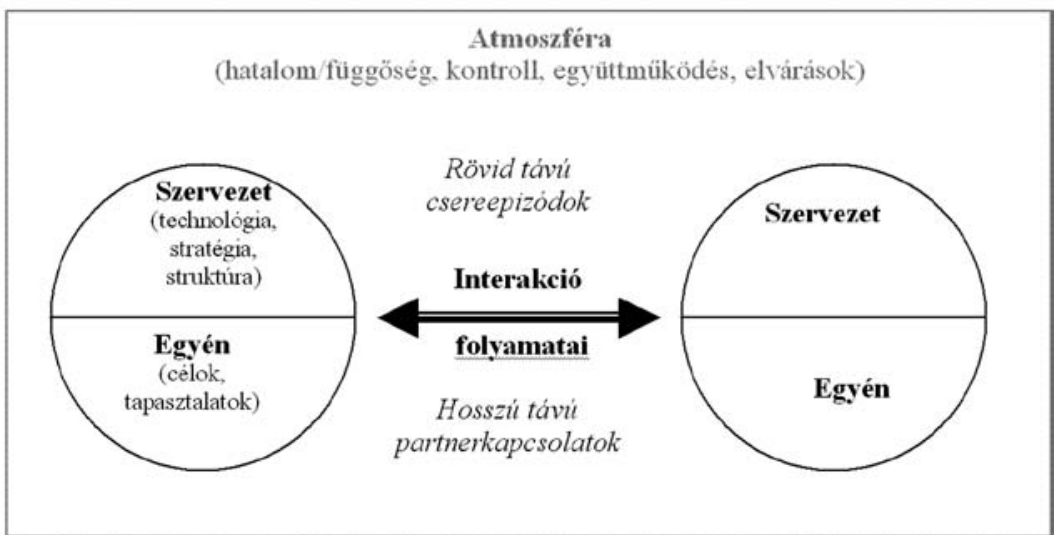

Forrás: Håkansson (1982: 32. o.)

Amint azt az első fejezetben, a vállalatok közötti kapcsolatok meghatározásakor már bemutattam, az epizódok sorozatos ismétlése folyamatokat alkot, létrejön az interakció, amelyeknek a szervezeteken belüli további intézményesülése erôsödô kötelékeket alakít ki a felek között, s megszületik a hosszú távú orientációjú kapcsolat.

Az interakció folyamatait nemcsak az egyes epizódok tartalma, hanem a kapcsolatban szerepló felek tulajdonságai is formálják, amelyek egyaránt kötődnek a szervezetekhez és a személyekhez. A szervezetekhez köthetố tulajdonságjegyek közül Håkansson a következóket emeli ki: a kapcsolat tárgyát képező termék technológiai tulajdonságai az egyik legfontosabb, legkritikusabb elemét jelenthetik a kapcsolatnak. 
A termék előállításának komplexitása, vevôi igényekhez való alakíthatósága, testreszabhatósága, fejleszthetôsége, kiforrottsága mind-mind hozzájárul ahhoz, hogy az interakció során a felek az együttmúködés hosszú távú elmélyítése, vagy éppen felbontása mellett döntenek-e. Az együttmúködó felek vállalatmérete szintén kulcsfontosságú elem, amely a két szereplő hatalmi-függôségi viszonyára, együttmúködés iránti nyitottságára, illetve alkalmazkodóképességére, rugalmasságára is hatással van. A felek stratégiája és szervezeti struktúrája nyilvánvalóan befolyásolják az együttmúködés konkrét folyamatait. Rövid távon a szervezeti struktúrát az interakció keretrendszerének tekinthetjük, amelyet azonban hosszú távon a kapcsolatok során felhalmozott eredmények és tapasztalatok átalakíthatnak. Az együttmúködés folyamatában jelentôs szerep jut nemcsak a szervezeteknek, hanem a személyeknek is, akik jellemzően a beszerzó, illetve értékesítő pozíciókat töltik be az egyes vállalatoknál. A kapcsolatot kialakító személyek tudása, értékrendje, motivációja, kultúrája, egymással kapcsolatos személyes tapasztalatai és elvárásai beépülnek a szervezetek közötti interakciók folyamatába, s sokszor akár jelentôs mértékben is befolyásolni tudják az együttmúködést.

Az interakció környezete azt a széles körü kontextust jelenti, amelyben az egyes kapcsolatok beágyazottan léteznek. A piaci szerkezet, azaz a beszállítói és vevői oldalon levő szereplők száma és koncentrációjának mértéke markánsan befolyásolja az egyes kapcsolatok múködését, illetve a beszállítók és a vevôk választási, váltási lehetôségeit. Ugyanilyen mély hatása lehet az egyes kapcsolatokra a vevói és beszállítói piacokat jellemzó dinamizmusnak is, amely alatt a szerző azt érti, hogy mennyire gyorsan fejlődik a piac, a már ismertetett piaci szerkezetek milyen mértékben változnak, jelennek-e meg új szereplők, termékek. A környezet további fontos eleme, hogy az adott diadikus kapcsolatot alakító vevô és beszállító hol, milyen pozícióban helyezkedik el az ellátási láncban, illetve milyen társadalmi viszonyrendszer, attitúd veszi körül a kapcsolatot. Ez utóbbi szociokulturális környezeten azokat a nemzeti, regionális vagy vállalatspecifikus hagyományokat, szokásokat, szemléletmódot értjük, amelyek indirekt módon beépülnek az egyes szervezeteket jellemző folyamatokba is.

A kapcsolatokat körülvevô atmoszféra a legnehezebben definiálható, megragadható eleme az együttmúködésnek. Mindazon tényezók összességét értjük rajta, amelyek hatással vannak az interakció folyamatainak kialakulására és tulajdonságjegyeire, és emellett a szereplők és a szereplók közötti folyamatok - hosszú távon
- maguk is befolyásolni tudják ezeket az elemeket. Az atmoszférát tehát az intézményesült partnerkapcsolati rutinok, illetve a partnerek jövőorientált világos elképzelései stabillá teszik. De ezzel együtt az atmoszféra egy dinamikus környezet is, hiszen a technológiai fejlődés, a piaci szervezeti változások s a partnerek epizódok során felhalmozott tapasztalata - jellemzóen hosszú távon - alkalmas aktuális állapotának megváltoztatására. Az atmoszféra kiemelt elemei: a tranzakciós költségek, a hatalmi-függóségi viszony és (az eróforrások feletti) kontroll. A hatalmon Håkansson elsôsorban befolyásolási képességet ért, amellyel a hatalmat birtokló vállalat befolyásolni tudja egy másik vállalat döntéseit és cselekvéseit annak akarata, illetve beleegyezése nélkül, sôt sokszor azzal ellenében. A hatalom egy jelentős lehetôség birtokosa számára arra, hogy az interakció folyamatait irányítsa, a kapcsolat hasznának és költségeinek elosztását a szereplók között befolyásolja. Ám konkrét, kapcsolatokban való megjelenése attól függ, hogy a hatalom birtokosa mennyit érzékeltet saját erófölényéból a másik féllel szemben. A két fél közötti összekapcsolódás szorossága szintén fontos eleme az egyes folyamatokat körülölelő atmoszférának. Håkansson megközelítése szerint minél több formális és informális kötelék ${ }^{8}$ létesül az együttmúködő felek között, a kapcsolat irányításának tranzakciós költségei annál alacsonyabbak lesznek. A kontroll funkciója és megjelenési formája általában az érzékeltetett hatalom szintjétôl függ. Az egymás folyamata, múködése felett gyakorolt kontroll magasabb szintje hozzájárulhat a másik döntéseivel kapcsolatos bizonytalanságok csökkenéséhez, s egyben meghatározza az egyes felek által birtokolt eróforrások, illetve a kapcsolat által teremtett értékek (hasznok) elosztását is. Fontos azonban megjegyezni, hogy a hatalmi-függôségi szituáció egyrészt mindig relatív, másrészt pedig semmiképpen sem állandó elem, hanem a tranzakciók során a felek bármelyike által elsősorban hosszú távon - megváltoztatható.

Az IMP Group és Håkansson (1982) az interakció- modell megalkotásával nagyon komplex és átfogó megközelítését adták a vállalatok közötti kapcsolatokat rövid és hosszú távon jellemzó folyamatoknak, illetve az azokat befolyásoló tényezőknek. Korai modelljük a vevő-beszállító kapcsolatok elemzésének egyik mérföldkövét jelenti, amely számos további publikáció és kutatás kiindulópontját képezi azóta is. Az IA bár több ponton törekszik a kapcsolatokra jellemzó dinamizmust megragadni, alapvető́en egy statikus pillanatfelvételt készít a vizsgált vállalatok közötti kapcsolat rendszerérôl. Elemzésében a vevoók és beszállítók között kialakuló kapcsolatok megítélésében a főszerepet fôként - a tisztán racionális költség- (és múködési) ha- 
tékonysággal szemben - olyan tényezók kapják, mint a rugalmas alkalmazkodás, a szervezeti és egyéni döntések alkalmával kifejezett együttmúködési készség és a bizalom. Az IA magatartásfelfogása nem opportunista: alapvetően kooperatív, és a környezeti-társadalmi viszonyokhoz rugalmasan illeszkedő, azokat elfogadó magatartást tekinti sajátjának.

Az elméletet ért kritikák a fenti megközelítést tartják túlságosan általánosnak. Ford (1998) megjegyzi, hogy az adaptációra és kooperációra való törekvés mellett azt sem szabad elfelejteni, hogy az üzleti kapcsolatokban részt vevő felekre a saját érdekeik követése, és a konfliktusok vállalása, esetleg generálása szintén általánosan jellemzô. A kooperatív vagy konfrontatív elemek közül azok kerülnek majd túlsúlyba magatartásukban, amelyekkel úgy érzik, eredményesebbek lehetnek, feltéve persze, hogy jól ítélik meg a partnert és az üzleti szituációt. Az IA szemléletével, kiindulópontjával kapcsolatos további észrevétel, hogy nem feltétlenül biztos az sem, hogy a partnerkapcsolatokra mindig hosszú távú orientáció a jellemző, hiszen vannak rövid távú és/vagy korlátozott időre szóló kapcsolatok, illetve a versengô irányítási stílus is jellemzően nem hosszú távú orientációjú szerződéses kapcsolatokat alkalmaz (Blomquist, 2002).

\section{Esettanulmány}

A cikk e fejezetében esettanulmányon keresztül szemléltetem a vevő-beszállító kapcsolat kialakulásának és további fejlődésének az elemzett vállalatok között kialakult, tapasztalt folyamatát, illetve a bemutatott IA elemzési modell segítségével értékelem a vizsgált kapcsolatban végbement változások kapcsolatra gyakorolt hatását.

A feltáró jellegú, kvalitatív kutatási technika alkalmazását a következô szempontok alapján tartottam indokoltnak választani s kutatásom folyamán alkalmazni:

- Bár a vállalatok közötti kapcsolatok - ezen belül kiemelten a vevô-beszállító kapcsolatok - struktúrájával, folyamataival, jellemzóivel számos publikáció foglalkozik, mégis inkább az mondhatjuk, hogy az adott témakör vizsgálatának nem alakult ki szilárd, általánosan elfogadott szempont- és fogalomrendszere. Inkább azzal a megállapítással élhetünk, hogy - az irodalomkutatás eredményeinek ismertetése során már bemutatott, részben egymás eredményeire támaszkodó, részben azoknak ellentmondó - kutatási irányok és megközelítések párhuzamosan léteznek a menedzsmentirodalomban. E szilárd definíciós struktúra hiánya a feltáró jellegú, a valóság mélyebb megismerését lehetôvé tevő kutatási technika alkalmazásának relevanciáját támaszthatja alá.

- A legtöbb, jelen cikkben is ismertetett elméleti megközelítés általánosan elfogadottnak tekinti azt az álláspontot, hogy a vállalatok közötti üzleti kapcsolatok elemei, az üzleti partnerek közötti együttmúködés folyamatai mindig csak az adott kapcsolatspecifikus kontextusban elemezhetốk, vizsgálhatók (Håkansson, 1982; Mohr Spekman, 1994; Möller - Wilson, 1995). Így a nevezett kapcsolatspecifikusság ${ }^{9}$ egyértelmúen végigkíséri a kutatás folyamatát és eredményeit, s elôrevetíti a kutatás megbízhatóságával kapcsolatban várhatóan felmerülő problémákat is.

Az esettanulmány alanya egy olyan üzleti kapcsolat, melyben egy hazai multinacionális élelmiszer-ipa$\mathrm{ri}^{10}$ vállalat a beszállítói pozícióban, illetve egy magyar tulajdonosi háttérrel rendelkezô nagykereskedő a vevői pozícióban található. Az esettanulmány kilenc vállalati mélyinterjú segítségével készült, amelyek közül ötöt a beszállító kereskedelmi vezetőjével, illetve értékesítési munkatársaival, négyet pedig a vevő ügyvezetőjével, beszerzési vezetójével, illetve beszerzési munkatársaival végeztem el, mert a vevő-beszállító kapcsolat szempontjából a nevezett pozíciókat betöltő személyek voltak a releváns interjúalanyok, hiszen elsősorban „rajtuk keresztül”, az ô irányításukkal zajlanak a vállalatok közötti együttmúködés folyamatai.

A kutatás eredményeinek értékelhetőségére megítélésem szerint a kvalitatív kutatásokra általánosan jellemző megállapítások mondhatók el. Érvényessége egyes esetekben meghaladhatja a hagyományos kvantitatív elemzésekét, ugyanis a kvalitatív módszertanok nagy elônye, hogy a valóság pontosabb és mélyebb megértését teszik lehetővé (Babbie, 1995). A kvalitatív kutatási eredmények megbizhatósága azonban problémás, ugyanis a kutatói szubjektivitás sem a kutatás folyamatából, sem a kutatási eredmények azonosításából és értelmezéséből nem szứrhető ki, így tehát egyáltalán nem bizonyos, hogy egy „megismételt” kutatási eljárás során egy másik társadalomkutató a vizsgált jelenségekból ugyanazon következtetéseket vonná le (Babbie, 1995). A kutatás jellegéból következően az eredmények általánosíthatósága ugyancsak korlátozott. Maxwell (1996) a kvalitatív kutatásoknál megkülönböztet úgynevezett külsớ és belsố általánosíthatóságot. A belsố általánosíthatóság esetén a kutatás eredményei a vizsgált egységre, csoportra vonatkoztatva általánosíthatók, míg a külsố általánosíthatóság esetén azt meghaladóan is érvényesek. Maxwell szerint a kvalitatív kutatások 
erejét a belsố általánosíthatóság adja, de a legtöbb esetben arra sem lát ellenérvet, hogy az eredményeket részben megváltozott kontextusban - általánosan, külsô értelemben is érvényesnek tekintsük.

Az elemzés fókuszában álló két vállalat kapcsolatának ,közös története” a kétezres évek elején kezdődött, amikor a multinacionális beszállító egy felvásárlás eredményeként megjelent a magyarországi piacon. A Kezdetekben alkalmanként zajlottak le értékesítési tranzakciók a felek között, amelynek során a vevő nagy mennyiségben vásárolt fóként ún. volumentermékeket (a beszállító által kapacitásai kihasználása érdekében nagyobb volumenben termelt, közepes [standard] vagy gyengébb minőségú [economy] eledeleket). A beszállító termékei a nagykereskedố vevői körében népszerúek voltak, így ezek a tranzakciók egyre gyakrabban ismétlődtek - epizódokká váltak -, illetve a megszokott termékek körén kívül egyre több, a beszállító által forgalmazott márkaterméket is vásárolt a vevô. „A beszállító relatíve olcsó, emellett jó ár-érték arányú eledelei megfeleltek a mi vevőkörünk igényeinek, emellett a rendelési, fizetési és szállítási feltételek is egészen kényelmesek voltak. Egyszóval elsố körben minden adott volt ahhoz, hogy egyre gyakrabban adjunk le megrendeléseket" - jellemzi a kapcsolat kezdeti lépéseit a vevói pozícióban levő nagykereskedő értékesítési igazgatója. Ezt a szakaszt tekinthetjük a Ford (1998) által elókapcsolati állapotnak nevezett stációnak, ugyanis a felek az egyes tranzakcióik során kapcsolatba léptek egymással, majd azok epizódokká fejlődtek. Ezek során a felek alapvetően elégedettek voltak egymással, az egyes epizódokhoz kapcsolódó akciók is rendben zajlottak: a beszállító a megadott időben és mennyiségben kedvezô ár-érték arányú termékeket szállított, a vevô pedig pontosan fizetett, egyre gyakrabban rendelt, s nem reklamált feleslegesen. Mindkét fél érzékelte, hogy ebben az együttmúködésben még lehet további potenciál, ezek az elképzelések azonban egyelőre kizárólag gondolati síkon maradtak. „Mindketten éreztük azért a másikról, hogy ebból a dologból többet is ki lehetne hozni, de még nem igazán tudtuk ennek a módját megtalálni, és amellett különbözô más irányokba is tapogatóztunk, külön-külön építettük saját üzletünket" - mondta egy interjú során a beszállító vállalat értékesítési vezetôje.

A sorozatosan ismétlődő, nagyobb volumenú és nagyobb választékot felölelố vevơi megrendelések megszaporodása eredményeként a beszállító is egyre inkább „odafigyelt” a vevőre. Értékesítési képviselője rendszeres idóközönként (kezdetekben csak havonta, majd hetente) felkereste a vevő beszerzési munkatársait, akik együtt egyeztették az értékesíteni- megrendelni kívánt termékek körét. Ennek kapcsán a beszállító különböző árakciókat, illetve egyéb promóciókat is felajánlott, hogy ösztönözze a vevő vásárlói hajlandóságát, lassanként kialakult egy operatív szinten jól funkcionáló együttmúködés a felek között. Ezt az időszakot megfelelően interpretálják a beszállító egyik értékesítési munkatársának beszámolójából vett következő mondatok: „Láttuk, hogy a vevő rendelései szépen gyarapodnak, s egyre nagyobb súlyt érnek el az értékesítésünkben. Elkezdtük tehát kicsit tudatosabbá tenni a dolgot, egyik értékesítési képviselônk munkájának tekintélyes részévé tettük a vevővel való kapcsolat részleteinek menedzselését. Annak érdekében, hogy gördülékenyen, probléma nélkül menjenek a rendelések, rendszeresen adatot szolgáltattunk a legkeresettebb, ún. slágertermékeink elérhetőségéról. Az értékesítés terén pedig elkezdtünk testre szabott árakciókat ajánlani, illetve a kiemelt idôszakokra különféle egyéb promóciókat is szerveztünk, mint mondjuk a garantált ajándék vagy a túltöltött termékek." A vevő kereslete relatíve magas szinten stabilizálódott, bár az általa rendelt termékek között a prémium kategóriát jelentô márkatermékek mellett még mindig az alacsonyabb minőségú volumentermékek maradtak túlsúlyban. Ezzel együtt a beszállító portfoliójában meghatározóvá vált a vevô részesedése, amit az egymással évente megkötött szállítási szerződés is megerősített. Természetesen ezek a Ford (1998) által feltáró szakasznak nevezett folyamatok évek alatt zajlottak le, s a megerôsödésükben nagy szerepet játszott, a felek elmondása szerint, a kölcsönös megbízhatóság, illetve az, hogy mindkét fél stratégiai céljaira - bár egymással ezt nem egyeztették - alapvetôen a növekedés, piacszerzés volt a jellemzô. Meg kell jegyezni azonban, hogy a fejlődés e két szakaszában a folyamatok alakítása, befolyásolása inkább ad hoc döntések mentén alakult, a tudatosság kevésbé volt jellemzô az együttmúködésre. A kapcsolat fejlődésének kezdeti szakaszokra jellemző spontaneitását megfelelően illusztrálják a vevő értékesítési vezetôjének szavai: „Azt mondhatjuk így visszatekintve, hogy talán a szerencsének köszönhetôen úgy alakult, hogy a saját piacainkon végül is ugyanazt a pályát jártuk be; mindketten növekedni akartunk, üzletet építeni, piacot szerezni, s ehhez mindkettőnknek kapóra jött a másik, így egyre inkább egymásra találtunk." Az elóbb említett tendenciákhoz, a lassanként egyre mélyebb tartalommal bíró értékesítési-beszerzési folyamatok kialakulásához köthetjük a két fél viszonyrendszerében az interakciók megjelenését, majd megszilárdulását. Ebben a fázisban az egyes epizódok önálló, interaktív folyamatokká formálódása, szubsztantív létezővé válása figyelhető meg, amely a kapcsolat következő fejlődési fázisára is áthúzódik. 
2006-2007 között a beszállító esetében stratégiai váltás zajlott le. A piacszerzési stratégia ugyanis érzékelhetően elérte, illetve túlhaladta tetópontját: a nyersanyagárak megemelkedtek, ezzel párhuzamosan a potenciális értékesítési csatornák telítődtek, így a relatíve olcsó, nagy kiszerelésú volumentermékek már nem generáltak profitot, így a cég eredménye egyre romlott, látszott, hogy az elôzố évek gyakorlata már nem tartható fenn. Erre válaszul a beszállító vállalat felülvizsgálta addigi stratégiáját, s a magas értékesítési volumen helyett a profitra helyezte a hangsúlyt. A stratégiaváltás szükségességének felismerésére, az új megközelítés relevanciájára a beszállító értékesítési igazgatója a következóképpen emlékszik vissza: „Gyakorlatilag az történt, hogy mindent úgy csináltunk, mint régen, de az eredmények és a nyereség helyett csak a növekvő készletek, csökkenó árbevétel és a meredeken visszaesố profit lett az eredmény. Eleinte nem értettük, mi történik, ezért nem is tudtunk hirtelen reagálni, majd a kezdeti sokk után elkezdtük megkeresni és elemezni a problémát. Rájöttünk, hogy azokból a termékekból aduk el sokat, amiken alig keresünk, a nagy marginnal rendelkező termékek viszont szúk részt tesznek ki értékesítésünkben. Ezért úgy döntöttünk, nincs más választásunk, mint hosszú távon megszabadulni az alacsony haszonkulcsú termékektől, s keményen ráfókuszálni a nagy margint termelő́kre - röviden összefoglalva: így alakult ki az ún. értékfókuszú stratégia." Ez a stratégiai váltás értelemszerúen a termékportfolio tisztítását, illetve átgondolását eredményezte: elsőrendú prioritásként szerepelt a leginkább rentábilis szuperprémium és prémium termékek értékesítése, $\mathrm{s}$ ezzel párhuzamosan az addig domináns volumentermékek esetében történő folyamatos visszavonulás. E stratégia megvalósításához a vevói oldalon is portfólioátalakításra volt szükség. A beszállító elhatározta, hogy csökkenti alacsony jövedelmezőségú vevơi számát, s azokra a partnerekre próbál meg koncentrálni, akik a tapasztalatok alapján megfelelő potenciállal bírnak az új stratégia gyakorlati alkalmazásához.

A fenti folyamatokkal párhuzamosan a 2000-res évek közepén a nagykereskedôi piacon gyorsuló ütemú koncentráció ment végbe, amely az esettanulmányunk vevơi alanyát jelentő vállalat megerősödését eredményezte. Az elemzett vállalat tovább erősítette piaci pozícióját, így az állateledelek terén ô rendelkezett a legnagyobb országos nagykereskedôi értékesítési hálózattal. E két, egymással párhuzamosan végbemenő folyamat a két vállalat fokozatos ,egymásra találását eredményezte". Lépésról lépésre ismerték fel stratégiájuk egybevágó elemeit, s kezdték összeegyeztetni azokat. Ebben a szakaszban az addig spontán módon menedzselt fo- lyamatokat már egyre tudatosabban koordinálták, s az operatívról felsővezetói szintre kerültek a legfontosabb kérdésekben történő egyeztetések. E találkozók egyre kevésbé voltak „operatív rutinmegbeszélések”, sokszor inkább a szervezeti, felsôvezetői döntéshozatali folyamatokba épültek be, amelynek lényege a célok és elvárások egyeztetése, az együttmúködés potenciális nyer-nyer kimeneteinek azonosítása volt. Az említett megbeszélések eredményeként letisztultak az együttmúködés stratégiai keretei, amelyet a felek hosszú távú keretszerződés formájában formalizáltak is. A kapcsolat fejlődésének e kiemelt szakaszát a nagykereskedó ügyvezetóje a következóképpen mutatta be:

„Azt már ugye említettük, hogy egymás fontosságát mindketten érzékeltük, csak nehezen jutottunk el odáig, hogy ezt magas szinten is megerősítsük. 2008 elején jött az áttörés, amikor a beszállító ügyvezetôje megkeresett minket és egy megbeszélést kezdeményezett. Mi ezt rögtön elfogadtuk, és belénk nyilallt, hogy ezt már igazából mi is régen megtehettük volna. Már az első alkalommal számos olyan kérdés körvonalazódott, amelyekből mindketten hosszú távon jól profitálhatunk, így megbeszéltük, hogy rendszeressé tesszük ezeket a találkozókat. Az első idôszakban kéthetente, most havonta találkozunk, megbeszéljük a futó projekteket, visszajelzést adunk egymásnak, s természetesen az esetlegesen felmerülő problémákról is egyeztetünk."

A beszállító szuperprémium termékeinek kizárólagos értékesítési jogát a vevőnek engedte át, a vevő pedig vállalta, hogy saját értékesítési csapatát úgy fejleszti, hogy egy éven belül országos értékesítési lefedettséget biztosít a termékeknek. Ez együtt járt új, magasan kvalifikált alkalmazottak felvételével, illetve az új és jelenlegi munkaerố képzésével. A fent bemutatott folyamatot nevezhetjük Ford (1998) interpretálásában fejlódési szakasznak, amikor is a felek azonosították stratégiájuk, piaci elképzeléseik komplementer pontjait, a formális és informális tárgyalásokon közösen kidolgozták hosszú távú együttmúködésük alapköveit. Közben olyan lényeges szociokulturális dimenziók is megerősödtek közöttük, mint a bizalom, vagy az ebból következő nyílt és ôszinte kommunikáció. Ezáltal gyakorlatilag megszületett a kapcsolat, ami a stabilizáló állapotban pedig elmélyült. A beszállító - egy szintén együttesen kidolgozott ,train the trainer” program keretében - a kapcsolat alapját képző szuperprémium termékekról, s az ehhez kapcsolódó speciális értékesítési technikákról, terméktulajdonságokról, értékesítés-ösztönzési lehetôségekról folyamatos tréninget tart a vevő kiemelt munkatársai számára, akik szervezett formában továbbadják ismereteiket a többi kollégájuknak. Emellett - amint arra az előbbi interjúrészletben is utaltunk 
- a felek kialakították a mind operatív, mind pedig felsóvezetôi szinten rendszeresen tartott találkozók gyakorlatát, ahol az értékesítés aktuális kérdéseit, illetve a jövőbeli stratégiából levezethető tervezési, megvalósítási feladatokat egyeztetik. A vevői (tovább)értékesítés hatékonyságának mérésére szintén közös gyakorlatot fejlesztettek ki, mint ahogyan a napi szinten felmerülố ad hoc problémák menedzselésére is ,jól bejáratott” rutineljárásokat, kommunikációs megoldásokat alkalmaznak. A kapcsolat fejlődése is némiképp felgyorsult: a stratégiai felismerés és koncepcióalkotás után az operatív- és menedzsmentfolyamatok rutinokká alakulása másfél-két év alatt napjainkra végbement.

A fejlődés legfontosabb fordulópontjait és az egyes fejlődési fázisokba való átmenet eseményeit a 6 . ábra szemlélteti. ségbiztosítás és nyomon követhetőség érdekében történő folyamatos fejlődést kényszerítette ki. Az elemzett időszakban nyilvánvalóan maga az állateledel-piac is fejlődött: az ún. volumentermékek esetén erôteljesen elôtörtek és többségi piaci részesedést szereztek a saját márkás termékek, s a fogyasztói igények is egyre polarizálódtak; a saját márka mellett a prémium termékek esetén volt tapasztalható - igaz, jóval mérsékeltebb - stabilizálódó kereslet. Ezek a változások érzékelhetố hatással voltak a szereplók stratégiájára is. A felek közötti hatalmi viszony a fejlódésnek, illetve stratégiai változásoknak, vevői megerősödésnek köszönhetően átalakult, s a kezdeti beszállítói erőfölény kiegyensúlyozott erôviszonnyá alakult át. Ennek megfelelően a folyamatok koordinációja (és kontrollja) a kezdeti beszállítói irányításról kölcsönösre váltott.

6. ábra A két fél között személyes és szervezetibizalmihidakegyaránt kialakultak, s a szervezeti kultúrájuk kezdeti problémás elemei is összecsiszolódtak. Klasszikusan ilyen problémás szervezeti kultúrabeli különbség volt a döntéshozatali gyakorlatban. A kevéssé tagolt, tulajdonosmenedzser által irányított magyar tulajdonú vevői szervezet a stratégiai döntéseket is relatíve gyorsan tudta meghozni, s az azokhoz való alkalmazkodás is hamar végbement. Az erôsen tagolt, bonyolult döntési hierarchiával rendelkező multinacionális beszállítónál egy-egy operatív döntésre is néha heteket kellett várni, s az alkalmazkodás is több idôt igényelt. Ez kezdetekben a vevót bizalmatlanná, türelmetlenné tette, ám ahogy

Forrás: saját szerkesztés

Az esettanulmány további részében az IA felhasználásával - annak statikus részeit módosítva - a fejlődés folyamatára, illetve „végeredményére” jellemző kapcsolatrendszert elemzem. A fejlődés teljes folyamata egy intenzív versenykörnyezetben ment végbe, ugyanis mind a beszállítói, mind pedig a vevối oldalon erós verseny tapasztalható a szereplók között, amely a koncentráció elôrehaladtával a vevôi „térfélen” valamelyest enyhült, a beszállítói oldalon viszont az EU-csatlakozás következtében tapasztalható szabad áruáramlás miatt tovább fokozódott. A kapcsolatot körülvevő szabályozási környezet egyre szigorodott, amely a vevői és beszállító oldalon egyaránt a minó- elmélyült a kapcsolat, s a felek egyre jobban megismerték egymás folyamatainak előnyeit és fejlesztendô területeit, ami végül a bizalmat is megerősítette. Az interakció folyamatai a kiinduló spontán ad hoc állapotból kiforrottá, tudatosan menedzseltté váltak, a kialakuló rutinok megfelelően erősítették a kapcsolatot. Végezetül az elózô szakaszban már elemzett szervezeti fejlődés mellett érdemes kiemelni az egyének közötti kötelékek kialakulását. A különböző informális találkozók hozzájárultak ahhoz, hogy a két szervezet munkatársai között is bizalmi kapcsolat alakult ki, amely rendkívül pozitív hatással bír a hatékony információáramlás és problémamegoldás terén. 


\section{Összefoglalás}

A szerzó bízik benne, hogy a cikkben összefoglalt ismeretek hozzásegítik az Olvasót a vevók és beszállítók közötti kapcsolatok tartalmának mélyebb megértéséhez, kontextusának elemzéséhez, illetve a bemutatott esettanulmány megfelelóen szemléltette az elméleti részben ismertetett kutatási irányokat.

A cikk elsősorban az IMP kutatóinak publikációit szintetizálja a vállalatok közötti kapcsolat, kiemelten a vevő-beszállító kapcsolat jelentéstartalmának megragadása érdekében. A kapcsolat szó jelentésének vizsgálata mellett bemutatja a vállalatok közötti kapcsolat tranzakciók szintjérôl történő kialakulásának legfontosabb állomásait, úgymint a csere, az epizódok, az interakció, a kapcsolat és a partnerkapcsolat állomásait, illetve az egyes együttmúködési fázisok jelentését is értelmezi. Következtetéseinek értelmében kapcsolat (i) két vállalat kölcsönös, önkéntes és koordinált tevékenysége, (ii) hosszú távú orientáció, kölcsönös adaptáció és jelentôs, felek közötti „összekapcsolódottság” jellemzi, amely túlmutathat az egyes vállalatok szervezeti keretein, (iii) elfogadott, közös cél érdekében jön létre, (iv) eredményeként az abban részt vevő felek kölcsönösen értéket teremtenek egymás számára. A kapcsolat fejlődésének kibontása mellett olyan további lényeges kérdéseket, megközelítéseket is bemutat az írás, mint a vevő-beszállító kapcsolat viszonyrendszerének egyik, nemzetközileg meghatározó elméleti kerete, illetve a kapcsolati szerződéselmélet következtetései.

A cikk második, tartalmi egységében a kapcsolat fejlődését, illetve a kapcsolat rendszerének megértését egy rövid esettanulmány szemléltette, amelynek célja a kapcsolat dinamizmusának érzékeltetése, illetve a fejlődés egyes kiemelt szakaszaiban zajló folyamatok hangsúlyozása volt. Az esettanulmány egyes pontjai jól megvilágítják a kapcsolat fejlődésében tapasztalható adaptációt, illetve az együttmúködési rutinok kialakulásának szövevényes rendszerét.

\section{Lábjegyzet}

${ }^{1}$ Több szerző gyakran cseretranzakcióként említi, lásd Kapás (2002), Bárdos (2004).

${ }^{2}$ A tranzakciós költségek elmélete ezeket az epizódokat nevezi cserének, lásd Williamson $(1975,1979)$ munkáit.

${ }^{3}$ Mandják (2005) ezt a tényezôt érintettek néven fordítja magyarra.

${ }^{4}$ Macneil (1980) nevéhez kapcsolódik a kapcsolati szerződéselmélet megalkotása, amelynek központi eleme, hogy a klasszikus szerződésjoggal szemben a szerzôdésekben figyelembe kell venni a társadalmi sokszínúséget, a társadalom által követett és elfogadott normákat és a jövőorientáltságot (Agárdi, 2005).

${ }^{5}$ A definíciót az idioszinkretikus beruházások miatt tüntettem fel a partnerkapcsolat meghatározásánál.
${ }^{6}$ Magas eszközspecifikusságú, nehezen konvertálható beruházás.

${ }^{7}$ Mandják (2005) interaktív megközelítésként fordítja munkájában.

${ }^{8}$ A késóbbi, 1995-ben megalkotott A-R-A modellben már konkrétan azonosítja és differenciálja e kötelékek tartalmát Håkansson.

${ }^{9}$ Nagy valószínúséggel ebból a kapcsolatspecifikusságból, illetve kontextusfüggóségból következik az előzó pontban említett letisztult definíciók és vizsgálati szempontok hiánya.

${ }^{10}$ Az elemzett iparág, ezen belül az állateledel.

\section{Felhasznált irodalom}

Agárdi I. (2005): Horizontális stratégiai szövetségek hatása a kiskereskedelmi vállalatok marketingstratégiájára és teljesítményére az élelmiszer- és napicikk-kiskereskedelemben. Doktori Értekezés, Budapesti Corvinus Egyetem, Gazdálkodástani Doktori Iskola

Andaleeb, S.S. (1995): Dependence Relations and Moderating Role of Trust: Implications for Behavioral Intentions in Marketing Channel. International Journal of Research in Marketing, Vol. 12, p. 157-172.

Anderson, J.C. - Narus, J. A. (1990): A Model of Distributor Firm and Manufacturer Firm Working Partnerships. Journal of Marketing, Vol. 54 (January), p. 42-58.

Anderson, J.C. - Narus, J.A. (1991): Partnering as a Focused Market Strategy. California Management Review, Vol. 33, No. 3, p. 95-113.

Babbie E. (1995): A társadalomtudományi kutatás gyakorlata. Balassi Kiadó, Budapest

Bárdos K. (2004): A tranzakciós költségek hatásának vizsgálata a hazai marhahússzektorban. URL: http://www. date.hu/acta-agraria/2004-13/bardos.pdf, letöltés dátuma: 2009. 08. 27.

Bensaou, M. (1999): Portfolios of buyer-supplier relationships. Sloan Management Review Vol, 40, No. 4, p. 35-45.

Blomqvist, K. (2002): Partnering in the Dyadic Environment: The Role of Trust in Assimetric Technology Partnership Formation. Acta Universitatis Lappenrantaensis, Vol. 122.

Blois, K.J. (1972): Vertical Quasi-Integration. Journal of Industrial Economics, Vol. 20, No. 3, p. 253-272.

Cox, A. (2001): Managing with Power: Strategies for Improving Value Appropriation from Supply Relationships. Journal of Supply Chain Management, Vol. 37, No. 2, p. 42-48.

Cox, A. (2004): Business relationship alignment: on the commensurability of value capture and mutuality in buyer and supplier exchange. Supply Chain Management, Vol. 9, No. 5, p. 410-420.

Creed, W.E.D. - Miles R.E. (1996): Trust in organisations: A conceptual framework linking organisational forms, managerial philosphies and the opportunity cost of controls. R.M. Kramer and T.R Tyler (Eds.): Trust in organisations: Frontiers of theory and research (p.1631), Sage, Thousand Oaks, CA 
Duffy, R. (2002): The Impact of Supply Chain Partnerships on Supplier Performance: A Study of the UK Fresh Produce Industry. PhD Thesis, Imperial College at Wye, University of London

Dyer, J.H. (1997): Effective interfirm collaboration: how firms minimize transaction cost and maximize transaction value. Strategic Management Journal Vol. 18, No. 7, p. 535-556.

Ellram, L. - Hendrick, R. (1995): Partnerig characteristics: a dyadic perspective. Journal of Business Logistics, Vol. 16, No. 1, p. 41-64.

Fearne, D. - Duffy, R. (2004): Buyer-Supplier Relationships: An Investigation of Moderating Factors on the Development of Partnership Characteristics and Performance. International Food and Agribusiness Management Review, Vol. 7, No. 2, p. 2-25.

Ford, D. (1998): Managing Business Relationships. John Wiley \& Sons, Chichester

Ford, D. - Håkansson, H. - Johansson, J. (1986): How Do Companies Interact? Industrial Marketing and Purchasing Vol. 1, No. 1, p. 26-41.

Ford, D. - Gadde, L. E. - Håkansson, H. - Snehota, I. Waluszewski, A. (2008): Analysing Business Interaction. 24th Annual IMPConference, Proceedings, Uppsala, Sweden

Gelei A. (2009): Hálózat - A globális gazdaság kvázi szervezete. Vezetéstudomány, XXXX. évf. 2009. 1. szám (január), 16-33. old.

Gelei, A. - Dobos, I. - Nagy, J. (2009): Determinant factors of relationship heaviness - An empirical investigation. 25th Annual IMPConference, Proceedings, Marseille, France

Håkansson, H. (1982): International Marketing and Purchasing of Industrial Goods: An Interaction Approach. Wiley, Chichester

Haytko, D. (1994): The Performance construct in Channels of distribution: A review and Synthesis. American Marketing Association (Winter), (1994), p. 262-71.

Holmund, M. (2004): Analyzing buinsess relationships and distinguishing different interaction levels. Industrial Marketing Management, Vol. 33, No. 2, p. 279-287.

Kapás J. (2002): Piacszerú vállalat és vállalatszerú piac. Közgazdasági Szemle, Vol. 49, No. 4, p. 320-333.

Liu, A.H. - Leach, M. (2003): Building Exit Barriers Through Value Management: Examining The Relationships Between Perceived Switching Costs And Customer Value. 21st Annual IMPConference, Proceedings, Logano, Schwitzerland

Macneil, I.R. (1980): The New Social Contract, An Inquiry into Modern Contractual Relations. Yale University Press, New Haven, CT.
Mandják T. (2005): Néhány gondolat a marketingról és az üzleti kapcsolatokról. BCE Vállalatgazdaságtan Intézet Múhelytanulmányok, 61. sz. tanulmány

Mandják T. - Durrieu, F. (2000): Understanding the noneconomic value of business relationships. 16th Annual IMPConference, Proceedings, Bath

Mandják, T. - Durrieu, F. - Bouzdine-Chameeva, T. (2002): Cognitive Mapping Methodology for Understanding of Business Relationship Value. Annual 18th IMPconference Proceedings, Dijon, France

Maxwell, J.A. (1996): Qualitative research design: An interactive approach. Sage, Thousand Oaks, California

Mitchell, W. - Singh, K. (1995): Survival of business using Collaborative Relationships to Commercialize Complex Goods. Strategic Management Journal, Vol. 17, No. 3, p. 169-195.

Mohr, J. - Spekman, R. (1994): Characteristics of Partnership success: Partnership attributes, communication behavior, and Concflict Resolution techniques. Strategic Management Journal, Vol. 15, No. 2, p. 135-152.

Möller, K. - Wilson, D.T. (1995): Business Relationships An Interaction Perspective. In: Business Marketing: An Interaction and Network Perspective; eds. Möller, K. Wilson, D.T., Kluwer Academic Publishers, Boston, p. 23-52.

Ring, P.S. - Van de Ven, A.H. (1993): Developmental Processes of Cooperative Interorganizational Relationships. Strategic Management Research Center, University of Minnesota

Stern, L.W. - Reve, T. (1980): Distribution Channels As Political Economies: A Framework For Comparative Analysis. Journal Of Marketing, Vol. 44, No. p. 52-64.

Skinner, S.J. - Gassenheimer, J.B. - Kelley, S.W. (1992): Co-operation In Supplier-Dealer Relations. Journal of Retailing, Vol. 68, No. 2

Tietz, B. (1993): Der Handelsbetrieb. Vahlen Verlag, 2. Auflage

Tuten, T.L. - Urban, D.J. (2001): An Expanded Model of Business-to-Business Partnership Formation and Success. Industrial Marketing Management, Vol. 30, p. 149-164.

Williamson, O.E. (1975): Markets and Hierarchies: Analysis and Antitrust Implications, The Free Press, New York

Williamson, O.E. (1979): Transaction Cost Economics: The Governance and Contractual Relations. Journal of Law and Economics, Vol. 22, p. 233-262.

Cikk beérkezet: 2010.3 . hó

Lektori vélemény alapján let véglegesítve: 2010. 5. hó 